\title{
STATUS PEMANFAATAN PERIKANAN TUNA MADIDIHANG (Thunnus albacares) BERDASARKAN MODEL BIOLOGI SCHAEFER
}

\author{
Utilization Status of Yellowfin Tuna (Thunnus albacares) Fishery Based on Schaefer's \\ Biology Model \\ Oleh:
}

Abgusta Fajri Wiranata ${ }^{1}$, Budy Wiryawan ${ }^{2}$, Sugeng Hari Wisudo ${ }^{2}$, Nimmi Zulbainarni ${ }^{3}$

\author{
${ }^{1}$ Mahasiswa Program Studi Teknologi Perikanan Laut, FPIK IPB; aftaafta@ymail.com \\ 2 FPIK, IPB; bud@psp-ipb.org; wisudo@yahoo.com \\ ${ }^{3}$ Sekolah Bisnis, IPB; nimmiz_reims@yahoo.com
}

Diterima: 15 Februari 2016; Disetujui: 19 Februari 2018

\begin{abstract}
There are two types of population growth function of the basic formulation of Schaefer's biology model, however in this study there is a difference in form and value of "r" as one of a biology parameter. In addition to the difference in the method by calculating the process of a and $b$ coefficient. The calculating process of $a$ and $b$ coefficient in Schaefer's biology model was conducted through linear regression which has not yet been exact. This is due to the model itself which is quadratic. Therefore to provide the solution is through quadratic process. The linear regression shows the value of $f_{m s y}$ and $Y_{\text {msy }} 1.40$ and 1.34 times smaller than quadratic process respectively. Based on the two graphs from the calculating process of a and $b$ coefficient, it can be concluded that the utilization of yellowfin tuna fishery was still not optimal. According to the result based on the linear and quadratic regression, the maximum production of yellowfin tuna can be increased to 664,037 and $877,340 \mathrm{~kg}$.
\end{abstract}

Keywords: Population growth function, Schaefer's Biology Model, Utilization status, Yellowfin tuna

\section{ABSTRAK}

Dua jenis fungsi pertumbuhan populasi menjadi dasar pembentukan model biologi Schaefer, namun dalam kajian ini terdapat perbedaan dalam bentuk dan nilai $r$ sebagai parameter biologi ditambah juga berdasarkan perbedaan metode perhitungan koefisien $a$ dan $b$. Metode perhitungan koefisien $a$ dan $b$ model biologi Schaefer melalui regresi linear masih kurang tepat, karena model biologi Schaefer berbentuk kuadratik, sehingga penyelesaiannya harus melalui proses kuadratik. Nilai $f_{m s y}$ dan $Y_{m s y}$ dari proses regresi linear memiliki nilai 1,40 dan 1,34 kali lebih rendah dari proses kuadratik. Berdasarkan kedua kurva dari kedua metode perhitungan koefisien $a$ dan $b$, maka status pemanfaatan perikanan tuna madidihang diduga masih belum optimal. Sehingga berdasarkan proses regresi linear dan kuadratik, maka produksi maksimal tuna madidihang masih dapat ditingkatkan sampai dengan 664.037 dan $877.340 \mathrm{~kg}$.

Kata kunci: Fungsi pertumbuhan populasi, Model biologi Schaefer, Status pemanfaatan Tuna madidihang

\section{PENDAHULUAN}

Status pemanfaatan suatu sumberdaya ikan laut sangat penting dilakukan, karena de- ngan mengetahuinya dapat diduga apakah upaya penangkapan yang telah dilakukan terhadap suatu sumberdaya memiliki status pemanfaatan yang belum optimal, sudah optimal atau telah 
berlebih. Ketiga jenis status pemanfaatan ini dapat dijadikan dasar bagi pembuat kebijakan dalam mengatur upaya penangkapan terhadap sumberdaya ikan dalam menghadapi masingmasing kondisi yang sedang dihadapi. Salah satu metode perhitungan analisis dalam menduga status pemanfaatan suatu sumberdaya ikan yaitu dapat melalui model biologi Schaefer.

Model biologi Schaefer dipilih sebagai metode analisis yang banyak digunakan oleh beberapa peneliti perikanan dalam memberikan dugaan terkait status pemanfaatan suatu sumberdaya ikan. Tidak hanya itu, model ini juga dikenal sebagai metode yang paling mudah dalam menghitung nilai upaya penangkapan dan produksi yang optimal dari suatu sumberdaya ikan.

Walaupun model biologi Schaefer dikenal sebagai metode yang paling mudah dan banyak digunakan oleh peneliti perikanan, tetapi prosesnya diduga masih terdapat kekeliruan dalam perhitungan yang masih terus dipertahankan hingga saat ini. Kekeliruan tersebut diduga terletak pada proses perhitungan untuk menghasilkan nilai koefisien $a$ dan $b$ yang melalui regresi linear, bahkan nilai koefisien dari proses regresi linear tersebut digunakan ke dalam fungsi kuadratik, padahal model biologi Schaafer merupakan fungsi kuadratik.

\section{METODE}

Data yang digunakan dalam kajian ini da- pat dilihat pada Tabel 1. Data tersebut merupakan data produksi/hasil tangkapan $(\mathrm{kg})$ dan upaya penangkapan (trip) tuna madidihang yang berasal dari tiga instansi yaitu PPP Labuhan Lombok, Yayasan Masyarakat dan Perikanan Indonesia (MDPI) dan USAID-IMACS Indonesia. Data tersebut mengasumsikan bahwa aktivitas penangkapan tuna madidihang berada di Laut Flores (Gambar 1), menggunakan pancing tangan (handline) dan didaratkan di PPP Labuhan Lombok.

Fungsi pertumbuhan populasi digunakan oleh para ahli sebagai dasar dalam menganalisis urutan pembentukan fungsi Maximum Sustainable Yield (MSY). Terdapat dua jenis fungsi pertumbuhan populasi (Tabel 2), fungsi pertumbuhan populasi 1 digunakan oleh Schaefer (1954) dan Anderson (2002) yang dikenal dengan persamaan Verhulst-Pearl logistic dan yang kedua digunakan oleh Bergh et al. (2006), Anderson dan Seijo (2010), Fauzi (2010) dan Zulbainarni (2012).

Verhulst-Pearl logistic dalam Schaefer (1954) beranggapan bahwa terdapat jumlah maksimum populasi $(x)$ yang dapat ditampung oleh suatu batasan area $(K)$ dengan tingkat pertumbuhan alamiah $(r)$ yang dimiliki oleh suatu jenis ikan per satuan waktu dan juga tidak disertai dengan kegiatan eksploitasi atau kegiatan penangkapan ikan.

Kegiatan eksploitasi atau menangkap ikan di suatu perairan membutuhkan berbagai sarana. Sarana tersebut merupakan faktor input

Tabel 1 Data produksi/hasil tangkapan dan upaya penangkapan tuna madidihang dari tahun 2010-2014 yang didaratkan di PPP Labuhan Lombok

\begin{tabular}{lcc}
\hline Tahun & Hasil Tangkapan $(\mathbf{k g}) \boldsymbol{Y}$ & Upaya Penangkapan (trip) $\boldsymbol{f}$ \\
\hline 2010 & 254.545 & 6.454 \\
2011 & 348.586 & 10.147 \\
2012 & 184.193 & 4.786 \\
2013 & 489.289 & 13.483 \\
2014 & 372.276 & 12.171 \\
\hline
\end{tabular}

Tabel 2 Dua jenis fungsi pertumbuhan populasi

\begin{tabular}{ll}
\hline Fungsi Pertumbuhan Populasi 1 & Fungsi Pertumbuhan Populasi 2 \\
\hline$\frac{d x}{d t}=P(x)=r x(K-x) \ldots \ldots \ldots(1.1)$ & $\frac{d x}{d t}=P(x)=r x\left(1-\frac{x}{K}\right) \ldots \ldots \ldots(1.2)$
\end{tabular}




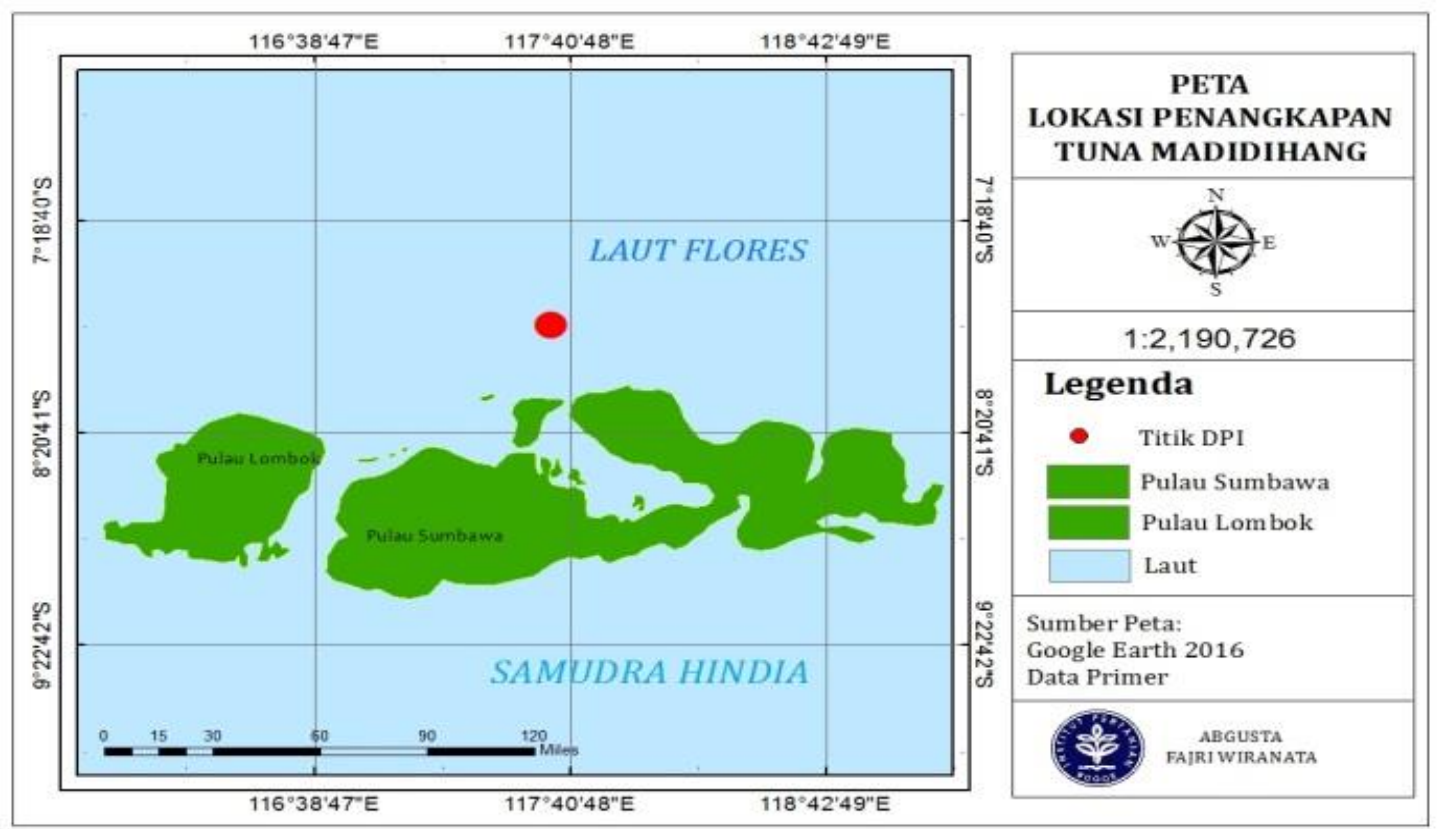

Gambar 1 Peta lokasi penangkapan tuna madidihang

yang disebut sebagai upaya penangkapan (effort) di dalam perikanan, sehingga hasil tangkapan $Y$ pada setiap waktu bergantung pada jumlah populasi awal periode dan jumlah upaya penangkapan yang digunakan, seperti dalam Conrad dan Clark (1987) yang dimodelkan sebagai berikut:

$Y=P(x, f)$

Fungsi $P(x, f)$ pada Persamaan (2) menghubungkan $x$ (jumlah populasi) dan $f$ (effort) dengan hasil tangkapan atau produksi, sehingga fungsi produksi atau penangkapan ikan yang sering digunakan dalam manajemen perikanan adalah sebagai berikut seperti dalam Conrad dan Clark (1987):

$Y=P(x, f)=q x f$

Catchability coefficient (q) pada Persamaan (3) diartikan sebagai proporsi stok ikan yang dapat ditangkap oleh satu unit upaya dan juga dapat menggambarkan tingkat efisiensi teknis dari penangkapan. Tingkat pertumbuhan alami/intrinsic growth rate $(r)$, daya tampung/ carrying capacity $(K)$ dan koefisien kemampuan tangkap/catchability coefficient $(q)$ disebut sebagai parameter biologi spesies ikan.

Aktivitas penangkapan ikan di suatu perairan mengakibatkan perubahan stok atau potensi sumberdaya perikanan. Perubahan tersebut merupakan selisih antara fungsi pertumbuhan populasi dengan fungsi penangkapan ikan. Selisih perubahan diasumsikan sama dengan nol, hal tersebut dikarenakan fungsi penangkapan ikan diasumsikan menangkap seluruh stok ikan di perairan. Selisih perubahan terse- but secara matematis dapat ditulis sebagai berikut:

$$
\begin{array}{r}
P(x, f)-P(x)=0 \\
P(\boldsymbol{x}, \boldsymbol{f})=\boldsymbol{P}(\boldsymbol{x}) \ldots \ldots \ldots \ldots \ldots \ldots \ldots \ldots \ldots \ldots
\end{array}
$$

Schaefer dalam mengembangkan konsepnya berdasarkan pada asumsi bahwa stok perikanan bersifat homogen (single stock atau spesies), fungsi pertumbuhan yang kuadratik dan area yang terbatas (Zulbainarni 2012). Sehingga dalam kajian ini hanya menggunakan tuna madidihang sebagai stok perikanan yang homogen, lokasi penangkapan yang dilakukan diasumsikan di Laut Flores.

Kita menyepakati bahwa dalam menentukan nilai Maximum Sustainable Yield (MSY) dilakukan melalui turunan pertama / diferensial dari fungsi kuadratik, sehingga $f_{m s y}$ dapat diperoleh:

$$
\begin{gathered}
Y=a f-b f^{2} \\
\frac{d Y}{d f}=a-2 b f \\
0=a-2 b f \\
2 b f=a
\end{gathered}
$$

$\frac{a}{2 b}=f_{m s}$

$f_{m s y}$ biasa disebut juga sebagai upaya penangkapan maksimum. Sementara untuk nilai produksi/hasil tangkapan maksimum $Y_{m s y}$ hanya memasukan Persamaan (5) ke dalam fungsi kuadratik seperti berikut:

$$
\begin{gathered}
Y=a\left(\frac{a}{2 b}\right)-b\left(\frac{a}{2 b}\right)^{2} \\
Y=\frac{a^{2}}{2 b}-\frac{b a^{2}}{4 b^{2}}
\end{gathered}
$$




$$
\begin{array}{r}
Y=\frac{a^{2}}{2 b}-\frac{a^{2}}{4 b} \\
Y=\frac{2 a^{2}-a^{2}}{4 b} \\
Y_{m s y}=\frac{a^{2}}{4 b} \ldots \ldots \ldots \ldots \ldots \ldots \ldots \ldots \ldots \ldots \ldots \ldots
\end{array}
$$

Langkah selanjutnya yaitu menghitung tingkat pemanfaatan $\left(T P_{t}\right)$ dan tingkat pengupayaan $\left(T P_{u_{t}}\right)$ dengan cara mempersenkan jumlah hasil tangkapan dan jumlah upaya pada tahun tertentu terhadap nilai hasil tangkapan optimum:

$$
\begin{aligned}
T P_{(i)} & =\frac{Y_{(i)}}{Y_{m s y}} \times 100 \% \\
T P_{u_{(i)}} & =\frac{f_{(i)}}{f_{m s y}} \times 100 \%
\end{aligned}
$$

Zulbainarni (2012) menyatakan bahwa untuk ketiga parameter biologi $(q, r$, dan $K)$ tersebut dapat dihitung dengan menggunakan algoritma Fox dengan formula:

$$
\begin{aligned}
& z=\left[\left(-\frac{a}{b}\right)-\left(\frac{C P U E_{t}+C P U E_{t+1}}{2}\right)\right] \\
& y=\left[\left(\frac{z}{C P U E_{t+1}}\right)+\left(\frac{1}{b}\right)\right] \ldots \cdots \cdots \cdots \cdots \cdots \\
& w=\left[\left(\frac{z}{C P U E_{t}}\right)+\left(\frac{1}{b}\right)\right] \ldots \cdots \cdots \cdots \cdots \cdots \cdots
\end{aligned}
$$

$$
\begin{aligned}
& q=\text { geomean }\left|\ln \frac{\frac{w}{y}}{z}\right| \\
& \boldsymbol{K}=\frac{\boldsymbol{a}}{\boldsymbol{q}} \ldots \ldots \ldots \ldots \ldots \ldots \ldots \ldots
\end{aligned}
$$

\section{HASIL}

Perbedaan koefisien kuadratik yang ditinjau dari parameter biologi spesies ikan berdasarkan dua jenis fungsi pertumbuhan populasi

Keberadaan dua jenis fungsi pertumbuhan populasi akan menyebabkan perbedaan nilai jumlah stok ikan. Para peneliti menyadari bahwa fungsi penangkapan ikan tidak akan menangkap seluruh stok ikan di perairan dalam satu waktu. Sehingga stok ikan yang tersisa pada satu waktu tersebut pada saat Persamaan 1 sampai 4 menjadi dasar maka bentuknya dapat dilihat pada Tabel 3.

Jika stok ikan di perairan digunakan ke dalam fungsi produksi atau penangkapan ikan, nilai $x$ yang berbeda tersebut juga mempengaruhi perbedaan nilai indikator biologi jika dimasukan ke dalam Persamaan (3), maka fungsi yang dihasilkan dapat dilihat pada Tabel 4.

Tabel 3 Jumlah stok ikan dari fungsi pertumbuhan populasi 1 dan 2

\begin{tabular}{cc}
\hline $\begin{array}{c}\text { Jumlah stok ikan dari Fungsi Pertumbuhan } \\
\text { Populasi } \mathbf{1}\end{array}$ & $\begin{array}{c}\text { Jumlah stok ikan dari Fungsi Pertumbuhan } \\
\text { Populasi } \mathbf{2}\end{array}$ \\
\hline$r x(K-x)=q x f$ & $r x\left(1-\frac{x}{K}\right)=q x f$ \\
$r(K-x)=q f$ & $1-\frac{x}{K}=\frac{q f}{r}$ \\
$K-x=\frac{q f}{r}$ & $1-\frac{q f}{r}=\frac{x}{K}$ \\
$K-\frac{q f}{r}=x \ldots \ldots \ldots(14.1)$ & $K\left(1-\frac{q f}{r}\right)=x \ldots \ldots(14.2)$ \\
\hline
\end{tabular}

Tabel 4 Fungsi MSY berdasarkan fungsi populasi 1 dan 2

\begin{tabular}{cc}
\hline $\begin{array}{c}\text { Fungsi } \text { MSYberdasarkan Fungsi } \\
\text { Pertumbuhan Populasi 1 }\end{array}$ & $\begin{array}{c}\text { Fungsi } \text { MSYberdasarkanFungsi } \\
\text { Pertumbuhan Populasi 2 }\end{array}$ \\
\hline$Y=q\left(K-\frac{q f}{r}\right) f$ & $Y=q\left[K\left(1-\frac{q f}{r}\right)\right] f$ \\
$Y=q f\left(K-\frac{q f}{r}\right)$ & $Y=q\left[K-\frac{q f K}{r}\right] f$ \\
$Y=q f K-\frac{q^{2} f^{2}}{r}$ & $Y=q f K-\frac{q^{2} f^{2} K}{r}$ \\
$Y=q K f-\frac{q^{2}}{r} f^{2} \ldots \ldots(15.1)$ & $Y=q K f-\frac{q^{2} K}{r} f^{2} \ldots . .(15.2)$ \\
$a=q K$ & $a=q K$ \\
$b=\frac{q^{2}}{r}$ & $b=\frac{q^{2} K}{r}$ \\
\end{tabular}


Terlihat bahwa kedua jenis Persamaan (15.1 dan 15.2) dapat membentuk fungsi kuadratik $Y=a f-b f^{2}$ yang masing-masing berbeda pada koefisien $b$. Koefisien $b$ berbeda karena memiliki bentuk parameter biologi spesies ikan yang berbeda.

\section{Perbedaan nilai koefisien $a$ dan $b$ melalui proses regresi linear dan kuadratik}

Persamaan (16) telah diketahui secara umum sebagai bentuk akhir dari penyederhanaan metode analisis Schaefer. Persamaan tersebut merupakan bentuk kuadratik yang harus ditentukan nilai koefisien $a$ dan $b$-nya untuk membentuk suatu pola, tetapi ahli perikanan dan kami memiliki perbedaan proses dalam perhitungan koefisien $a$ dan $b$ yang menyebabkan nilai Maximum Sustainable Yield (MSY) juga berbeda.

\section{Regresi Linear}

Dalam penentuan nilai koefisien $a$ dan $b$ selama ini masih berpatokan terhadap proses regresi linier yang Sparre dan Venema (1999), Fauzi (2010) dan Zulbainarni (2012) jabarkan, yaitu:

$$
\frac{Y}{f_{(i)}}=a-b f_{(i)}
$$

Persamaan (17) memperlihatkan bahwa jika melalui proses regresi linear, maka ruas kiri dan kanan dari sama dengan pada Persamaan (16) dibagi oleh $f$. Pembentukan persamaan seperti itu sah secara matematika sehingga penentuan parameter $(a$ dan $b)$ dalam Siagian dan Sugiarto (2002):

$$
\begin{aligned}
& b=\frac{n\left[\sum\left(\left(f_{(i)}\right)\left(\frac{Y_{(i)}}{f_{(i)}}\right)\right)\right]-\left[\left(\sum f_{(i)}\right)\left(\sum \frac{Y_{(i)}}{f_{(i)}}\right)\right]}{n\left[\sum\left(f_{(i)}^{2}\right)\right]-\left[\left(\sum f_{(i)}\right)^{2}\right]} \ldots \ldots \\
& a=\frac{\sum \frac{Y_{(i)}}{f_{(i)}}-b\left(\sum f_{(i)}\right)}{n} \ldots \ldots \ldots \ldots \ldots \ldots \ldots \ldots \ldots \ldots \ldots \ldots \ldots
\end{aligned}
$$

\section{Kuadratik}

Dalam kajian ini ditemukan proses yang berbeda yaitu perhitungan secara langsung berdasarkan metode kuadratik, maka untuk menghitung koefisien $a$ dan $b$ pada Persamaan (16) yaitu:

$$
\begin{aligned}
& A=n\left[\sum\left(f_{(i)}\right)\left(Y_{(i)}\right)\right] \ldots \ldots . \\
& B=n\left[\sum\left(\left(f_{(i)}\right)^{4}\right)\right] \ldots \ldots \ldots \\
& C=n\left[\sum\left(\left(f_{(i)}\right)^{3}\right)\right] \ldots \ldots \ldots \\
& D=n\left[\sum\left(\left(f_{(i)}\right)^{2}\right)\left(Y_{(i)}\right)\right] \ldots \\
& E=n\left[\sum\left(\left(f_{(i)}\right)^{2}\right)\right] \ldots \ldots \ldots \\
& F=E B-C^{2} \ldots \ldots \ldots \ldots \ldots \ldots
\end{aligned}
$$

Setelah keenam nilai dari persamaan tersebut telah diketahui, maka nilai $a$ dan $b$ dapat dihitung dengan:

$$
\begin{aligned}
& a=\frac{A B-C D}{F} . \\
& b=\frac{D E-A C}{F} .
\end{aligned}
$$

Hasil dari perhitungan dalam menentukan nilai koefisien ( $a$ dan $b$ ) antara proses regresi linear dan kuadratik menunjukkan bahwa secara keseluruhan memiliki nilai yang berbeda (Tabel 5). Nilai koefisien a melalui regresi linear lebih besar dari pada kuadratik dan $b$ sebaliknya.

Tabel 5 Perbedaan nilai koefisien $a$ dan $b$ berdasarkan regresi linear dan kuadratik

\begin{tabular}{lll}
\hline Koefisien & Regresi linear & Kuadratik \\
\hline$a$ & 42,1129 & 39,6748 \\
\hline$b$ & $-0,000668$ & $-0,000448$ \\
\hline
\end{tabular}

\section{Perbedaan nilai Maximum Sustainable Yield (MSY) melalui proses regresi linear dan kuadratik}

\section{Regresi Linear}

Setelah didapatkan nilai koefisien a dan $b$ maka persamaan (17) menjadi:

$\frac{Y}{f}=42,1129-0,000668 f$
Berdasarkan panduan yang dijelaskan oleh Sparre dan Venema (1999), Fauzi (2010) dan Zulbainarni (2012) maka nilai koefisien tersebut dapat digunakan dalam persamaan kuadratik seperti di bawah ini lalu dideferensialkan untuk mendapatkan nilai $f_{m s y}$ dan $Y_{m s y}$.

$Y=42,1129 f-0,000668 f^{2}$ 


\section{Kuadratik}

Setelah didapatkan nilai koefisien a dan $b$ maka secara kuadratik menjadi:

$Y=39,6748 f-0,000448 f^{2}$

Sehingga persamaan kuadratik tersebut dapat dilanjutkan melalui diferensial untuk mendapatkan nilai $f_{m s y}$ dan $Y_{m s y}$.

Hasil dari perhitungan dalam menentukan nilai $M S Y$ antara proses regresi linear dan kuadratik menunjukkan bahwa secara keseluruhan memiliki nilai yang berbeda (Tabel 6). Nilai $f_{m s y}$ dan $Y_{m s y}$ dari proses kuadratik 1,40 dan 1,34 kali lebih besar dari regresi linear.

Kurva fungsi $M S Y$ dari proses regresi linear juga lebih kecil daripada kuadratik (Gambar 2), hal tersebut dikarenakan nilai $f_{m s y}$ dan $Y_{m s y}$ dari proses kuadratik 1,40 dan 1,34 kali lebih besar dari regresi linear.

Tabel 6 Perbedaan nilai $M S Y$ melalui proses regresi linear dan kuadratik

\begin{tabular}{ccc}
\hline MSY & Regresi linear & Kuadratik \\
\hline$f_{m s y}($ trip $)$ & 31.536 & 44.227 \\
$Y_{m s y}(\mathrm{~kg})$ & 664.037 & 877.340 \\
\hline
\end{tabular}
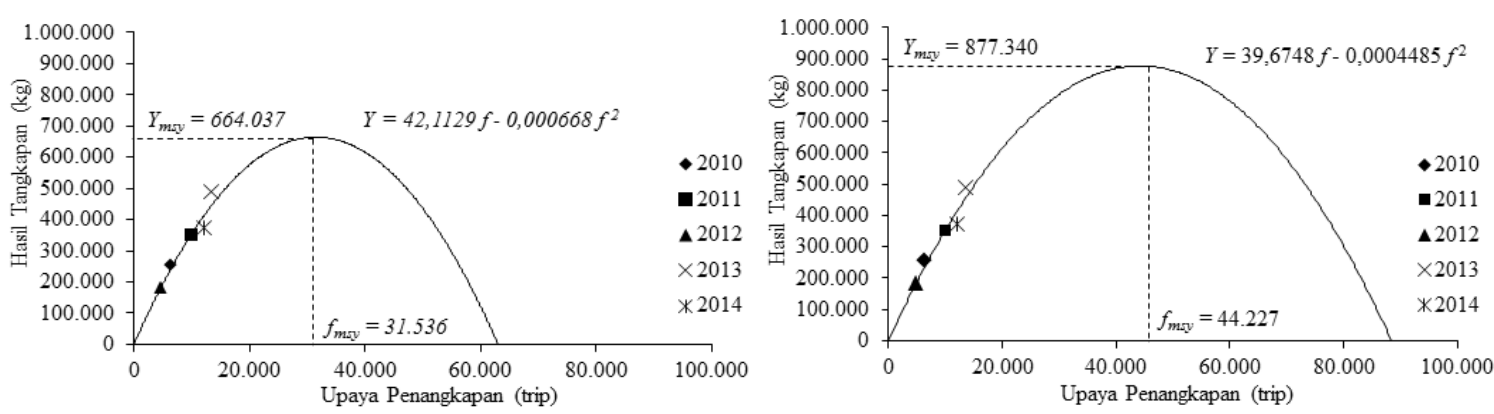

Gambar 2 Perbedaan kurva MSY berdasarkan proses regresi linear (kiri) dan kuadratik (kanan)

Tabel 7 Perbandingan nilai tingkat pemanfaatan dan pengupayaan tuna madidihang berdasarkan teknik linear dengan kuaratik

\begin{tabular}{ccccc}
\hline \multirow{2}{*}{ Tahun } & \multicolumn{2}{c}{ Regresi linear } & \multicolumn{2}{c}{ Kuadratik/polinomial ordo dua } \\
\cline { 2 - 5 } & $T P_{(i)}$ & $T P_{\boldsymbol{u}(\boldsymbol{i})}$ & $T P_{(\boldsymbol{i})}$ & $T P_{\boldsymbol{u}(\boldsymbol{i})}$ \\
\hline $\mathbf{2 0 1 0}$ & $38,33 \%$ & $20,47 \%$ & $29,01 \%$ & $14,59 \%$ \\
$\mathbf{2 0 1 1}$ & $52,49 \%$ & $32,17 \%$ & $39,73 \%$ & $22,94 \%$ \\
$\mathbf{2 0 1 2}$ & $27,74 \%$ & $15,18 \%$ & $20,99 \%$ & $10,82 \%$ \\
$\mathbf{2 0 1 3}$ & $73,68 \%$ & $42,75 \%$ & $55,77 \%$ & $30,49 \%$ \\
$\mathbf{2 0 1 4}$ & $56,06 \%$ & $38,59 \%$ & $42,43 \%$ & $27,52 \%$ \\
\hline
\end{tabular}

Lebih besarnya nilai $M S Y$ pada proses kuadratik dibandingkan regresi linear, jelas akan membuat persentase tingkat pemanfaatan dan pengupayaan pada proses kuadratik/polynomial ordo dua lebih rendah daripada regresi linear. Hal tersebut dapat dilihat pada Tabel 7 , dimana tingkat pemanfaatan (TP) dan pengupayaan $\left(T P_{u}\right)$ pada proses regresi linear 1,34 dan 1,40 kali lebih besar daripada kuadratik/polynomial ordo dua. Pada tahun 2012 memiliki nilai lebih kecil karena hasil tangkapan dan upaya penangkapannya paling rendah dari keseluruhan tahun tersebut. Berbeda halnya pada tahun 2013, dimana hasil tangkapan dan upaya penangkapannya paling tinggi dari keseluruhan tahun.
Sama dengan parameter fungsi produksi lestari, keseluruhan nilai parameter biologi baik berdasarkan Persamaan (1.1 dan 1.2) yang melalui proses regresi linear dan kuadratik berbeda (Tabel 8 ). Nilai intrinsic growth rate $(r)$ terlihat bahwa di Persamaan 1.2 baik dari proses regresi linear ataupun kuadratik bernilai lebih besar dari Persamaan 1.1, tetapi nilai $r$ dari proses kuadratik bernilai lebih besar dari regresi linear, begitu juga dengan daya dukung lingkungan/carrying capacity $(K)$ dari proses kuadratik bernilai lebih rendah dari regresi linear. Penggambaran Tabel 8 mengenai nilai parameter biologi fungsi pertumbuhan populasi dapat dilihat pada Gambar 3. 
Tabel 8 Nilai parameter biologi berdasarkan regresi linear dan kuadratik

\begin{tabular}{|c|c|c|c|c|}
\hline \multirow[b]{2}{*}{$\begin{array}{l}\text { Parameter } \\
\text { Biologi }\end{array}$} & \multicolumn{2}{|l|}{ Regresi linear } & \multicolumn{2}{|l|}{ Kuadratik } \\
\hline & $\begin{array}{l}\text { Fungsi } \\
\text { Pertumbuhan } \\
\text { Populasi } 1\end{array}$ & $\begin{array}{l}\text { Fungsi } \\
\text { Pertumbuhan } \\
\text { Populasi } 2\end{array}$ & $\begin{array}{l}\text { Fungsi } \\
\text { Pertumbuhan } \\
\text { Populasi } 1\end{array}$ & $\begin{array}{l}\text { Fungsi } \\
\text { Pertumbuhan } \\
\text { Populasi } 2\end{array}$ \\
\hline$r$ & 0,00000026 & 0,8352 & 0,00000075 & 1,6259 \\
\hline$q$ & 0,00001324 & & 0,00001838 & \\
\hline$K$ & $3.180 .248,4$ & & 2.158.408,1 & \\
\hline
\end{tabular}
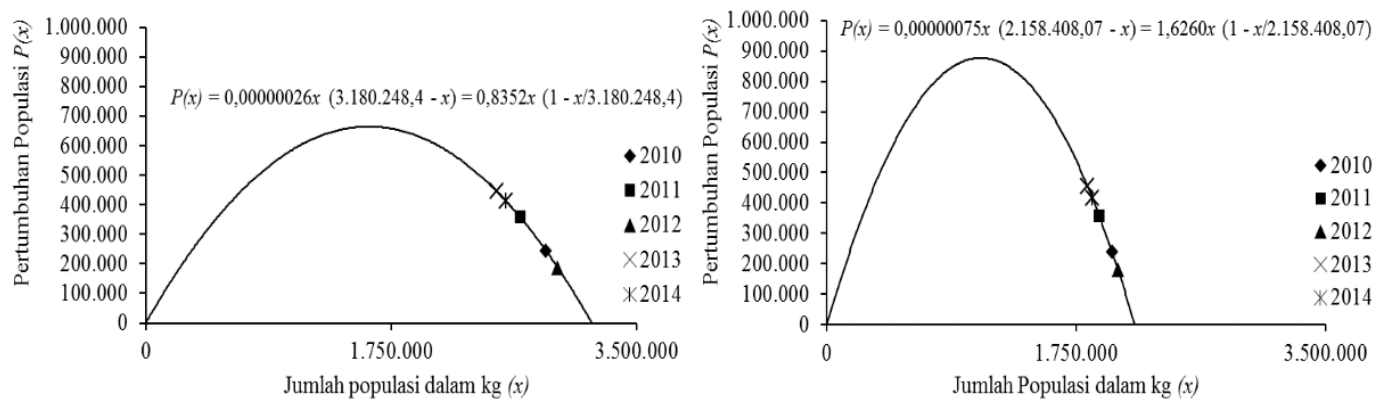

Gambar 3 Perbedaan kurva fungsi pertumbuhan populasi dari proses analisis hubungan regresi linear sederhana (kiri) dan hubungan kuadratik (kanan)

\section{PEMBAHASAN}

Langkah awal yang sangat penting untuk diperhatikan sebelum melakukan analisis data menggunakan model biologi Schaefer yaitu pemilihan salah satu fungsi pertumbuhan populasi. Jika hal tersebut tidak dilakukan akan terjadi kekeliruan terhadap nilai intrinsic growth rate $(r)$ yang menjadi penilaian laju pertumbuhan populasi suatu spesies ikan. Hasil perhitungan pada Tabel 8 yang memperlihatkan bahwa nilai $r$ dari setiap jenis fungsi pertumbuhan populasi menghasilkan nilai yang berbeda secara signifikan. Tentunya hal ini akan sangat berpengaruh terhadap suatu interpretasi hasil terhadap laju pertumbuhan suatu populasi, terlebih lagi jika dilakukan perhitungan melalui analisis pendekatan model biologi multispesies.

Para ahli dan peneliti dalam bidang perikanan menunjukkan dan memberikan cara analisis data untuk membuat model biologi Schaefer yaitu dengan proses regresi linear sederhana yang menghubungkan upaya penangkapan $(f)$ dengan hasil tangkapan per upaya penangkapan $\left(\frac{Y}{f}\right)$ (Sparre dan Venema 1999; Budiman et al. 2006; Kadafi et al. 2006; Irham et al. 2008; Sobari dan Muzakir 2008; Sobari et al. 2008; Haryani et al. 2009; Diniah et al. 2010; Fauzi 2010; Sobari dan Febrianto 2010; Hulaifi 2011; Rosalina et al. 2011; Sibagariang et al. 2011; Sriati 2011; Wuaten et al. 2011; Yusfiandayani dan Sobari 2011; Utami et al. 2012; Triarso 2012; Zulbainarni 2012;
Karnan et al. 2012; Kawimbang et al. 2012; Irhamsyah et al. 2013; Kumaat et al. 2013; Latupeirissa 2013; Nurhayati 2013; Rahmawati et al. 2013; Febriani et al. 2014; Sandria et al. 2014; Sharfina et al. 2014; Patria et al. 2014; Noija et al. 2014; Santoso 2016), tetapi dalam penelitian ini telah diperlihatkan bahwa pernyataan dan penggunaan metode tersebut masih belum tepat karena proses regresi linear yang digunakan hanya untuk mempermudah perhitungan nilai koefisien fungsi MSY ( $a$ dan $b$ ) dan ternyata memiliki perbedaan nilai 1,3 sampai 1,4 kali lebih rendah dari kuadratik.

Proses regresi linear yang mungkin memang disarankan oleh Schaefer pada saat itu dapat diduga bahwa perkembangan ilmu pengetahuan dan mesin hitung belum sehebat atau secanggih pada saat ini, sehingga dapat disarankan untuk menggunakan proses regresi linear untuk menentukan koefisien $a$ dan $b$ dalam fungsi $M S Y$-nya. Indra (2007) menyatakan bahwa estimasi koefisien $a$ dan $b$ untuk persamaan yield-effort dari model Schaefer melibatkan teknik non regresi linear dan dalam penelitian Pangalila et al. (2014) menggunakan teknik regresi polinomial untuk menentukan koefisien-koefisien dan menghitung nilai sustainable yield.

Persamaan 16 merupakan hilir dari penjabaran model biologi Schaefer. Fungsi tersebut memiliki sifat kuadratik yang menghubungkan upaya penangkapan $(f)$ dengan hasil tangkapan $(Y)$. Pada Persamaan 16 juga dapat dilihat 
secara detail bahwa fungsi tersebut tidak memiliki intersep atau intersep $=0$. Hal tersebut sangat jelas dan masuk akal karena intersep akan memberikan suatu nilai positif atau negatif pada saat upaya penangkapan nol atau tidak ada. Jadi secara umum, Persamaan 16 memiliki arti bahwa pada saat upaya penangkapan nol atau tidak ada, maka hasil tangkapan juga tidak ada. Kalangan matematika dan statistika sudah membuat penyelesaian untuk menghitung seluruh parameter dan intersep dari sifat kuadratik atau polynomial ordo dua tersebut, tetapi sampai saat ini penulis belum menemukan yang memaparkan bagaimana cara menghilangkan intersep atau membuat intersep $=0$. Maka dari itu, pada penelitian ini dibuat rumus seperti pada Persamaan (20 sampai 27) yang dikembangkan dari Siagian dan Sugiarto pada tahun 2002.

Proses perhitungan parameter fungsi produksi lestari $a$ dan $b$ yang melalui regresi linear pada Persamaan (17 sampai 19) akan membuat a menjadi intersep, sehingga jika pada saat tidak ada penangkapan atau $f=0$, maka akan membuat $\frac{Y}{f}$ memiliki nilai yang sama dengan a. Secara matematis, jika menggunakan proses regresi linear, sesungguhnya nilai kofisien $a$ dan $b$ adalah milik upaya penangkapan $(f)$ dengan hasil tangkapan per upaya penangkapan $\left(\frac{Y}{f}\right)$, bukan upaya penangkapan $(f)$ dengan hasil tangkapan $(Y)$, maka tidaklah sesuai nilai koefisien tersebut digunakan lalu dideferensialkan dalam fungsi produksi lestari.

Sparre dan Venema (1999), Fauzi (2010) dan juga Zulbainarni (2012) menjelaskan bahwa koefisien fungsi produksi lestari ( $a$ dan $b$ ) pada model Schaefer dihitung melalui proses hubungan regresi linear antara upaya penangkapan dengan hasil tangkapan per upaya penangkapan. Padahal dari ketiga sumber tersebut juga sudah menjelaskan bahwa grafik Schaefer berbentuk parabola yang persamaannya kuadratik. Jadi, jika proses regresi linear antara upaya penangkapan dengan hasil tangkapan per upaya penangkapan ditujukan hanya untuk mempermudah perhitungan parameter fungsi produksi lestari ( $a$ dan $b$ ) model Schaefer, maka seharusnya memiliki nilai yang sama dengan perhitungan melalui kuadratik dalam membentuk kurva parabola.

Pada proses regresi linear, nilai $Y_{m s y}$ dan $f_{m s y}$ lebih kecil dibandingkan dengan pangkat dua, begitu juga dengan nilai tingkat pemanfaatan dan pengupayaan tuna madidihang. Perbedaan nilai antara kedua proses tersebut disebabkan oleh perbedaan nilai parameter $a$ dan $b$ dari setiap proses analisis pada fungsi produksi lestari. Perbedaan proses perhitungan koefisien $a$ dan $b$ juga mempengaruhi perbedaan nilai parameter biologi.

Walaupun terdapat perbedaan kurva, model dan nilai pada kedua proses tersebut, posisi lima tahun dalam fungsi produksi lestari dan pertumbuhan populasi alami memiliki persamaan dalam hal letak posisi dan status pemanfaatannya. Pada Gambar 2 menunjukan hasil tangkapan pada tahun 2011 dan 2014 berada di dalam kurva, tetapi pada tahun 2010, 2012 dan 2013 berada di luar kurva. Status pemanfaatan tuna madidihang berdasarkan kedua kurva tersebut diduga masih dalam keadaan belum optimal, hal tersebut dilihat berdasarkan titik lima tahun pada kedua kurva yang terletak disebelah kiri dari nilai $f_{m s y}$ dan di bawah nilai $Y_{m s y}$, sehingga masih dimungkinkan untuk menambahkan upaya penangkapannya.

\section{KESIMPULAN}

Kajian ini telah membandingkan proses perhitungan berdasarkan dua jenis fungsi pertumbuhan populasi dan dua proses perhitungan koefisien $a$ dan $b$ dalam model MSY Schaefer. Berdasarkan penurunan persamaan dan hasil perhitungan, maka kedua jenis fungsi pertumbuhan populasi memiliki nilai intrinsic growth rate $(r)$ yang berbeda. Hasil menunjukan bahwa proses regresi linear belum tepat untuk proses perhitungan parameter $a$ dan $b$, karena berdasarkan model Schaefer dan asumsi yang digunakannya, maka disarankan untuk menggunakan proses hubungan kuadratik dalam proses perhitungan parameter $a$ dan $b$. Nilai produksi lestari untuk $Y_{m s y}=877.340 \mathrm{~kg}$ dan $f_{m s y}=44.227$ trip. Berdasarkan titik lima tahun dari data, maka status pemanfaatan perikanan tuna madidihang diduga masih belum optimal.

\section{SARAN}

Bagi para peneliti yang merencanakan penggunaan model Schaefer harus mengerti terlebih dahulu mengenai fungsi MSY secara matematika. Perhitungan dalam penentuan koefisien $a$ dan $b$ disarankan menggunakan jalur kuadratik, karena lebih sesuai dengan asumsi yang digunakan oleh Schaefer dan kaidah matematika.

Pada penelitian ini hanya menggunakan data sebanyak lima tahun, sehingga perlu dilakukan penelitian lagi dengan data yang lebih dari lima tahun. Bagi yang melanjutkan penelitian ini disarankan untuk membandingkan nilai koefisien determinasi dan korelasi dari kedua jenis proses hubungan tersebut. 
Hasil analisis menduga bahwa tuna madidihang yang ditangkap di Laut Flores lalu didaratkan di PPP Labuhan Lombok masih belum optimal, sehingga masih dapat dilakukan penambahan upaya penangkapan sampai dengan batas $f_{m s y}$.

\section{DAFTAR PUSTAKA}

Anderson LG, Seijo JC. 2010. Bioeconomics of Fisheries Management. lowa (US): Wiley-Blackwell.

Anderson LG. 2002. Fisheries Economics. Volume 1: Collected Essays. International Library of Environmental Economics and Policy. Burlington (US): Ashgate.

Bergh JCJM, Hoekstra J, Imeson R, Nunes PALD, Blaeij AT. Bioeconomics Modelling and Valuation of Exploited Marine Ecosystems. Volume 28: Economy and Environment. Dordrecht (NL): Springer.

Budiman, Supriharyono, Asriyanto. 2006. Analisis Sebaran Ikan Demersal Sebagai Basis Pengelolaan Sumberdaya Pesisir di Kabupaten Kendal. Jurnal Pasir Laut. 2(1): 52-63.

Diniah, Sobari MP, Primadianti I. 2010. Aspek Bioteknik dalam Pemanfaatan Sumberdaya Ikan Teri di Perairan Palabuhanratu Kabupaten Sukabumi. J Tek Per Kel. 1(1): 95-104.

Fauzi A. 2010. Ekonomi Perikanan: Teori, Kebijakan dan Pengelolaan. Jakarta (ID): Gramedia.

Febriani PR, Mudzakir AK, Asriyanto. 2014. Analisis CPUE, MSY, dan Usaha Penangkapan Lobster (Panulirus sp.) di Kabupaten Gunungkidul. Journal of Fisheries Resources Utilization Management and Technology. 3(3): 208-217.

Haryani EBS, Fauzi A, Monintja DR. 2009. Analisis Bionomi Ikan Karang di Perairan Kabupaten Raja Ampat, Provinsi Papua Barat. Bul PSP. XVIII(3): 185-193.

Hulaifi. 2011. Pendugaan Potensi Sumberdaya Perikanan Laut dan Tingkat Keragaan Ekonomi Penangkapan Ikan (Kasus di TPI Sendang Biru Kabupaten Malang). J Mat Sai Tek [internet]. [diunduh 2016 April 22]; 12(2):113-126. Tersedia pada: http:// jurnal.ut.ac.id/JMST/article/download/ 197/189.

Indra. 2007. Model Bio-Ekonomi Opsi Rehabilitasi Sumber Daya Perikanan di Provinsi
Nanggroe Aceh Darussalam [disertasi]. Bogor (ID): Institut Pertanian Bogor.

Irham, Wisudo SH, Haluan J, Wiryawan B. 2008. Analisis Pengembangan Mini Purse Seine Berbasis Optimasi Sumberdaya Ikan Pelagis Kecil di Provinsi Maluku Utara. Bul PSP. 17(1): 188-204.

Irhamsyah, Azizah N, Aulia H. 2013. Tingkat Pemanfaatan dan Potensi Maksimum Lestari Sumberdaya Cumi-Cumi (Loligo sp.) di Kabupaten Tanah Bumbu Provinsi Kalimantan Selatan. Bul PSP. 21(2):181192.

Kadafi M, Widaningroem R, Soeparno. 2006. Aspek Biologi dan Potensi Lestari Sumberdaya Lobster (Panulirus spp.) di Perairan Pantai Kecamatan Ayah Kabupaten Kebumen. Jurnal Perikanan. VIII(1): 108117.

Karnan, Baskoro MS, Iskandar BH, Lubis E, Mustaruddin. 2012. Potensi dan Tingkat Pemanfaatan Sumberdaya Ikan Unggulan di Perairan Selat Alas Nusa Tenggara Barat. Bul PSP. 20(4): 391-401.

Kawimbang E, Paransa IJ, Kayadoe ME. 2012. Pendugaan Stok dan Musim Penangkapan Ikan Julung-julung dengan Soma Roa di Perairan Tagulandang, Kabupaten Kepulauan Siau Tagulandong Biaro. Jurnal IImu dan Teknologi Perikanan Tangkap. 1(1): 10-17.

Kumaat J, Haluan J, Wiryawan B, Wisudo SH, Monintja DR. 2013. Potensi Lestari Perikanan Tangkap di Kabupaten Kepulauan Sitaro. Mar Fish. 4(1): 41-50.

Latupeirissa IL. 2013. Pendugaan Stok Ikan Tembang (Sardinella fimbriata) pada Laut Flores (Kab. Bulukumba, Bantaeng, Jeneponto dan Takalar). AGRICOLA. 3(2): 136-149.

Noija D, Martasuganda S, Murdiyanto B, Taurusman AA. 2014. Potensi dan Tingkat Pemafaatan Sumerdaya Ikan Demersal di Perairan Pulau Ambon-Provinsi Maluku. J Tek Per Kel. 5(1): 55-64.

Nurhayati A. 2013. Analisis Potensi Lestari Perikanan Tangkap di Kawasan Pangandaran. Jurnal Akuatika. IV(2): 195-209.

Pangalila FPT, Budiman J, Telleng ATR, Reppie E. 2014. Kajian Perikanan Tangkap Mene maculata di Teluk Buyat. Jurnal IPTEKS PSP. 1(2): 103-111.

Patria AD, Adrianto L, Kusumastanto T, Kamal MM, Dahuri R. 2014. Status Pemanfaatan Sumberdaya Udang oleh Perikanan 
Skala Kecil di Wilayah Pesisir Kabupten Cilacap. Mar Fish. 5(1): 49-55.

Rahmawati M, Fitri ADP, Wijayanto D. 2013. Analisis Hasil Tangkapan per Upaya Penangkapan dan Pola Musim Penangkapan Ikan Teri (Stolephorus spp.) di Perairan Pemalang. Journal of Fisheries $R e$ sources Utilization Management and Technology. 2(3): 213-222.

Rosalina D, Adi W, Matasari D. 2011. Analisis Tangkapan Lestari dan Pola Musim Penangkapan Cumi-Cumi di Pelabuhan Perikanan Nusantara Sungailiat-Bangka. Maspari Journal. 02(2011): 26-38.

Sandria F, Fitri ADP, Wijayanto D. 2014. Analisis Potensi dan Tingkat Pemanfaatan Sumberdaya Ikan Demersal di Perairan Kabupaten Kendal. Journal of Fisheries Resources Utilization Management and Technology. 3(3): 10-18.

Santoso D. 2016. Potensi Lestari dan Status Pemanfaatan Ikan Kakap Merah dan Ikan Kerapu di Selat Alas Propinsi Nusa Tenggara Barat. Jurnal Biologi Tropis. 16(1): 15-23.

Schaefer MB. 1954. Some Aspects of the Dynamics of Populations Important to the Management of the Commercial Marine Fisheries. IATTC Bull [internet]. [diunduh 2016 Jan 06]; 1(2): 27-56. Tersedia pada:

https://www.iattc.org/PDFFiles2/Bulletins/ IATTC-Bulletin-Vol-1-No-2.pdf

Sharfina M, Boer M, Ernawati Y. Potensi Lestari Ikan Selar Kuning (Selaroides leptolepis) di Perairan Selat Sunda. Mar Fish. 5(1): 101-108.

Siagian D, Sugiarto. 2002. Metode Statistika untuk Bisnis dan Ekonomi. Jakarta (ID): Gramedia.

Sibagariang OP, Fauziyah, Agustriani F. 2011. Analisis Potensi Lestari Sumberdaya Perikanan Tuna Longline di Kabupaten Cilacap, Jawa Tengah. Maspari Journal. 03(2011): 24-29.

Sobari MP, Diniah, Widiarso DI. 2008. Analisis "Maximum Sustainable Yield" dan "Maxi- mum Economic Yield" Menggunakan BioEkonomik Model Statis Gordon-Schaefer dari Penangkapan Spiny Lobster di Wonogiri. Jurnal Ilmu-ilmu Perairan dan Perikanan Indonesia. 15(1): 35-40.

Sobari MP, Febrianto A. 2010. Kajian BioTeknik Pemanfaatan Sumberdaya Ikan Tenggiri dan Distribusi Pemasarannya di Kabupaten Bangka. J Tek Per Kel. 10(1): 15-29.

Sobari MP, Muzakir. 2008. Kajian Ekonomi Pemanfaatan Sumberdaya Ikan Teri di Kabupaten Agam, Provinsi Sumatera Barat. Bul PSP. XVII(3): 372-381.

Sparre P, Venema SC. 1998. Introduction to Tropical Fish Stock Assessment. Part 1: Manual. FAO Fisheries Technical Paper, No. 306.1, Rev. 2. Rome (IT): FAO.

Sriati. 2011. Kajian Bio-Ekonomi Sumberdaya Ikan Kakap Merah yang didaratkan di Pantai Selatan Tasikmalaya, Jawa Barat. Jurnal Akuatika. II(2): 79-90.

Triarso I. 2012. Potensi dan Peluang Pengembangan Usaha Perikanan Tangkap di Pantura Jawa Tengah. Jurnal Saintek Perikanan. 8(1): 65-73.

Utami DP, Gumilar I, Sriati. 2012. Analisis Bioekonomi Penangkapan Ikan Layur (Trichirus sp.) di Perairan Parigi Kabupaten Ciamis. Jurnal Perikanan dan Kelautan. 3(3): 137-144.

Wuaten JF, Reppie E, Labaro II. 2011. Kajian Perikanan Tangkap Ikan Julung-julung (Hyporhamphus affinis) di Perairan Kabupaten Kepulauan Sangihe. Jurnal Perikanan dan Kelautan Tropis. VII(2): 80-86.

Yusfiandayani R, Sobari MP. 2011. Aspek Bioteknik dalam Pemanfaatan Sumberdaya Rajungan di Perairan Teluk Banten. Jurnal Teknologi Perikanan dan Kelautan. 1(2): 71-80.

Zulbainarni N. 2012. Teori dan Praktik Pemodelan Bioekonomi dalam Pengelolaan Perikanan Tangkap. Cetakan Pertama. Bogor (ID): IPB Press. 